\title{
Temperate-like stand dynamics in relict Mediterranean-fir (Abies pinsapo, Boiss.) forests from southern Spain
}

\author{
Juan C. LinARES ${ }^{1 *}$, José A. CARreira ${ }^{2}$ \\ ${ }^{1}$ Departamento de Sistemas Físicos, Químicos y Naturales, Universidad Pablo de Olavide. Ctra. Utrera km. 1, 41002 Sevilla, Spain \\ ${ }^{2}$ Departamento de Biología Animal, Biología Vegetal y Ecología, Universidad de Jaén, Ed. B3, Paraje las Lagunillas s/n, 23071 Jaén, Spain
}

(Received 18 August 2008; revised version 3 December 2008; accepted 28 February 2009)

Keywords:

Abies pinsapo /

stand structure /

forest dynamic /

land-use change /

gap-phase regeneration /

Mediterranean-type ecosystems

Mots-clés :

Abies pinsapo /

structure des peuplements /

dynamique forestière /

changement d'affectation des terres /

phase de régénération par trouées /

écosystèmes méditerranéens

\begin{abstract}
- Introduction and statement of the research questions: Gap dynamics have been widely studied in forests of Abies spp. from temperate and boreal regions. The local microclimate and competition for light have been identified as the main factors controlling changes in species composition and canopy structure, however little is known on dynamics of such forests in Mediterranean.

- Experimental design and aims: We studied forest structure and dynamics of Abies pinsapo stands in southern Spain, in contrasting habitats and successional status. In addition past regeneration patterns and their relationship to canopy structure, disturbances and forest-use history were investigated. - Results: Stands structure attributes were within the range described for temperate conifer biomes. The age structure revealed two main cohorts comprised of a few $>100$ year-old trees and abundant younger trees established in a single recruitment event after the stands were protected in the 1950s. Initial growth-rate analyses indicated that $A$. pinsapo regenerated mainly in small canopy gaps, while only $15 \%$ recruited from the forest understorey. For the last ten years, basal area increment was lower than $10 \mathrm{~cm}^{2} \mathrm{y}^{-1}$ in $91 \%$ of studied trees and growth rate differences between trees narrowed.

- Conclusion: Stand dynamics in A. pinsapo forests maintain general features of temperate fir forests. Tree establishment over time and current stand structure fit to known changes in forest use. Widespread growth decline trends might be linked to stand stagnation and global warming.
\end{abstract}

Résumé - La dynamique des forêts reliques de sapin méditerranéen (Abies pinsapo, Boiss.) du sud de l'Espagne est identique à celle des peuplements tempérés.

- Introduction et état des questions de recherche : Les dynamiques des trouées ont été largement étudiées dans les forêts d'Abies spp. à partir des régions tempérées et boréales. Le microclimat local et la compétition pour la lumière ont été identifiés comme les principaux facteurs de contrôle des changements dans la composition des espèces et la structure du couvert, mais on sait peu de choses sur la dynamique de ces forêts dans les écosystèmes méditerranéens.

- Plan expérimental et objectifs : Nous avons étudié la structure de la forêt et la dynamique de peuplements d'Abies pinsapo dans le sud de l'Espagne, dans des habitats contrastés et dans des états d'évolution successifs. En outre, les modèles passés de régénération et leurs relations avec la structure du couvert, les perturbations et l'histoire de l'utilisation des forêts ont été étudiés.

- Résultats : Les attributs de structure des peuplements se situent dans la gamme décrite pour les biomes de conifères tempérés. La structure des âges a révélé deux cohortes principales composées de quelques vieux arbres d'un âge supérieur à 100 ans, et de nombreux jeunes arbres établis dans un seul évènement de régénération après que les peuplements aient été protégés dans les années 1950. Les premières analyses des taux de croissance ont indiqué que $A$. pinsapo s'est régénéré principalement dans les petites trouées, tandis que seulement $15 \%$ des arbres ont été recrutés dans le sous-bois. Au cours des dix dernières années, l'augmentation de la surface terrière a été inférieure à $10 \mathrm{~cm}^{2} \mathrm{an}^{-1}$ chez $91 \%$ des arbres étudiés et les différences entre les taux de croissance des arbres étaient réduites. - Conclusion : Les dynamique des peuplements d'A. pinsapo conservent les caractéristiques générales des forêts de sapins tempérés. L'installation des arbres et la structure actuelle des peuplements permettent de connaître les changements dans l'utilisation de la forêt. La baisse généralisée des tendances de croissance pourrait être liée à la stagnation du peuplement et au réchauffement de la planète.

\footnotetext{
*Corresponding author: calderon@ujaen.es
} 


\section{INTRODUCTION}

Structure and stand dynamics of forests of Abies spp. have been widely studied in temperate (Dobrowolska and Veblen, 2008), sub-alpine (Antos and Parish, 2002; Donnegan and Rebertus, 1999), and boreal (Kneeshaw and Bergeron, 1998; McCarthy, 2001) regions. Such studies have revealed that minor perturbations, subsequent canopy-gap characteristics, the local microclimate, and demographic as well as ecophysiological traits of the species, are generalised and major factors driving tree replacement and autogenic succession in such forests, as is the case for other types of mesic forest ecosystems (Nolet et al., 2008). Gap replacement models have, therefore, been proposed as a general framework to explain forest-stand dynamics in temperate and mesic regions.

On the other hand, human land use has a direct impact on forest ecosystems, and land-use history is a key issue to understand their current structure and long-term dynamics (Abrams and Orwig, 1996). Depending on the disturbance regime resulting from human activities, the tree-age structure of forests can range from even-aged, when regeneration occurs as a single recruitment event following a major perturbation, to allaged, when low-intensity uses allow a continuous regeneration pattern and gap-type dynamics (Veblen, 1992). As a result, gap-dynamics theory is being increasingly incorporated into management protocols for the sustainable use of boreal and temperate forests (Coates and Burton, 1997).

Despite their wide applicability, the suitability of gapdynamic models for Mediterranean conditions has been questioned (Pausas, 1999). Several reasons are proposed to explain such shortcomings, including summer drought, fire, and the distinctive human land-use history in the Mediterranean basin compared to temperate regions of Europe and North America. Some of the processes (e.g., competition for light and selfthinning), which underlie gap dynamics in temperate forest ecosystems, may differ under a Mediterranean climate, since soil moisture can be a decisive factor in addition to light availability. In fact, many studies have reported that vertical growth of Mediterranean tree species is not controlled by apical dominance, as is common in temperate forests (Vilà and Sardans, 1999), because shade tolerance is not the main regulator of forest succession under Mediterranean conditions (Benayas, 1998; Lookingbill and Zavala, 2000). All this suggests that increasing seasonality and summer drought, as predicted by climate-change models for temperate-boreal regions of Europe, will have profound consequences on the stand structure and gap dynamics of forest ecosystems, including Abies spp. (Aussenac, 2002).

Relict Mediterranean fir ecosystems and, in particular, endemic Abies pinsapo Boiss. forests from southern Spain, provide an opportunity to test the robustness of gap-dynamics theory for temperate forest succession under increased climatic seasonality. This fir grows in small and isolated populations in climatic refuges on north-facing slopes between 1000-1800 m a.s.l. These Pinsapo forests were severely damaged over the centuries through a variety of unsustainable practices such as overgrazing, logging and pollarding. Following the conservation measures implemented and the progressive abandonment of traditional uses in the late 1950s, the fragmented populations expanded and the scattered remaining stands became denser, which provides a range of locations varying widely in their land-use history and forest canopy structure.

The objectives of this study were: (i) To characterize stand structure and dynamics of Spanish A. pinsapo forests. (ii) To investigate relationships between forest-use history, age structure, growth trends and canopy structure. (iii) To consider possible effects of the mediterranean seasonality on the stand and gap dynamics of a temperate-like conifer forest.

\section{MATERIALS AND METHODS}

\subsection{Species and site descriptions}

Abies pinsapo Boiss. is a relict, circum-Mediterranean fir species, endemic to some coastal mountain ranges of southern Spain (West Betic Range) and northern Morocco (Rif Mountains) (Barbero and Quézel, 1975). In southern Spain, their forests currently occupy 3600 ha, distributed in three main areas. An earlier study of the structural characteristics of Pinsapo forests was restricted to one of the remnant areas (Sierra de Grazalema) and covered a small fraction of the overall structural variability (Arista, 1995). Our study was conducted at the other two locations (Tab. I): the Sierra de las Nieves (including two sites, the Yunquera and Ronda forests) and the Sierra Bermeja (Los Reales site). All these sites are in public lands owned by municipalities and historic land-uses varied widely.

In Sierra de las Nieves, Pinsapo forests develop mostly on calcareous substrates (limestone and dolomite) and show the widest range of canopy structure. Young forests, which recovered since protection measures were taken in the middle of the 20th century, appear at the Yunquera site; whereas old forests exist at the Ronda site (Alvarez Calvente, 1994). At Sierra Bermeja, Pinsapo forests grow on serpentines and peridotites. These substrates contain large quantities of mafic minerals ( $\mathrm{Mg}$ and Fe compounds) and some trace elements ( $\mathrm{Ni}$, $\mathrm{Cr}, \mathrm{Co}$ ), as well as low concentrations of $\mathrm{Ca}$ and other major elements $(\mathrm{N}, \mathrm{K}, \mathrm{P})$. They give rise to soils with unfavourable mineral composition and edaphic conditions, resulting in specific structural and functional adaptive features in plant species (Proctor, 1999; Brady et al., 2005).

\subsection{Stand selection}

Seven pinsapo stands of ca. 5 ha, which had not been disturbed by intense logging or fires in the last $50 \mathrm{y}$, were selected after an extensive field survey and a review of forest administration reports. The selection of stands was based on two primary characteristics: to include the two main parent materials mentioned above; and to consider stands of mature trees in which the dominant cover types were trees that have reached their maximum size growth stage, and younger stands regenerated mainly in the second half of the 20th century (Tab. I). Five of these were located at Sierra de las Nieves: stands $\mathrm{C} 1$ and $\mathrm{C} 2$ in the Yunquera forests, and stands C3, C4, and C5 in the Ronda forest. Along this sequence, soils range from Calcic and Typic Haploxerepts to Typic Calcixerolls and Lytic Haploxerolls, with a mesic moisture regime (Liétor et al., 2003). Another two stands were 
Table I. Locations and general characteristics of sampling stands. The successional stage of the forest stand at each sampling stands was preliminarily assessed on the basis of forest-management history and field observations, and each plot was assigned to one of three categories (1: young; 2: stem exclusion; and 3: old growth stand).

\begin{tabular}{|c|c|c|c|c|c|c|c|c|c|}
\hline $\begin{array}{l}\text { Locality } \\
\text { (parent material) }\end{array}$ & Site & Plot & $\begin{array}{l}\text { Latitude } \\
\text { (N) }\end{array}$ & $\begin{array}{l}\text { Longitude } \\
\text { (W) }\end{array}$ & $\begin{array}{l}\text { Elevation } \\
\text { (m) }\end{array}$ & Aspect & $\begin{array}{l}\text { Slope } \\
(\%)\end{array}$ & $\begin{array}{l}\text { Mean annual } \\
\text { temperature } \\
\left({ }^{\circ} \mathrm{C}\right)\end{array}$ & $\begin{array}{l}\text { Annual } \\
\text { precipitation } \\
(\mathrm{mm})\end{array}$ \\
\hline \multirow{3}{*}{$\begin{array}{l}\text { Sierra de las } \\
\text { Nieves }\end{array}$} & \multirow{2}{*}{ Yunquera } & $\mathrm{C} 1$ & $36^{\circ} 43^{\prime} 29^{\prime \prime}$ & $4^{\circ} 58^{\prime} 09^{\prime \prime}$ & 1258 & $\mathrm{NE}$ & 38 & 12.6 & 1200 \\
\hline & & $\mathrm{C} 2$ & $36^{\circ} 43^{\prime} 25^{\prime \prime}$ & $4^{\circ} 57^{\prime} 59^{\prime \prime}$ & 1195 & NW & 41 & 12.9 & 1200 \\
\hline & \multirow{3}{*}{ Ronda } & $\mathrm{C} 3$ & $36^{\circ} 43^{\prime} 10^{\prime \prime}$ & $5^{\circ} 00^{\prime} 29^{\prime \prime}$ & 1240 & NW & 21 & 11.9 & 1300 \\
\hline \multirow[t]{2}{*}{ (Calcareous) } & & $\mathrm{C} 4$ & $36^{\circ} 41^{\prime} 27^{\prime \prime}$ & $5^{\circ} 01^{\prime} 44^{\prime \prime}$ & 1644 & $\mathrm{~N}-\mathrm{NW}$ & 41 & 11.6 & 1400 \\
\hline & & $\mathrm{C} 5$ & $36^{\circ} 41^{\prime} 25^{\prime \prime}$ & $5^{\circ} 02^{\prime} 04^{\prime \prime}$ & 1564 & N-NW & 45 & 11.6 & 1400 \\
\hline Sierra Bermeja & \multirow{2}{*}{ Los Reales } & $\mathrm{S} 1$ & $36^{\circ} 29^{\prime} 07^{\prime \prime}$ & $5^{\circ} 12^{\prime} 24^{\prime \prime}$ & 1414 & $\mathrm{~N}-\mathrm{NE}$ & 20 & 12.0 & 1300 \\
\hline (Serpentine) & & $\mathrm{S} 2$ & $36^{\circ} 29^{\prime} 09^{\prime \prime}$ & $5^{\circ} 12^{\prime} 27^{\prime \prime}$ & 1427 & $\mathrm{~N}$ & 70 & 12.0 & 1300 \\
\hline
\end{tabular}

chosen at Sierra Bermeja (stand S1 and S2), where soils are mainly mesic Oxiaquic Hapludoll. Climatic conditions are comparable at all the study sites (Tab. I).

\subsection{Structural description and analysis}

Four tree-size categories were differentiated to characterise the canopy structure in the selected stands: (i) seedlings, with stem basal diameter $(\mathrm{BD})<0.3 \mathrm{~cm}$ and height $(\mathrm{H})<1 \mathrm{~m}$; (ii) saplings, stem with $\mathrm{BD}$ between 0.3 and $3 \mathrm{~cm}$ and $H<1 \mathrm{~m}$, (iii) poles, with stem diameter at breast height (DBH) of between 3 and $10 \mathrm{~cm}$, and $H$ of between 1 and $4 \mathrm{~m}$; and (iv) trees, with $\mathrm{DBH}>10 \mathrm{~cm}$ and $H>4 \mathrm{~m}$. Different sizes sampling units were used to get representative censuses of stem density and basal area in the case of smaller and larger trees. The first three categories were sampled using ten randomly located $2 \times 25 \mathrm{~m}^{2}$ quadrats per stand, and the fourth category by four $50 \times 50 \mathrm{~m}^{2}$ squares per stand. All individuals were measured for stem diameter (BD or DBH) and classified as alive or dead, the latter class being subdivided into standing dead trees, fallen trees, and stumps. The height of every stem less than $4 \mathrm{~m}$ tall was also measured. Seedling age was recorded by counting the number of stem flakes or knots. Gap abundance was calculated by a point-intersect method ( $n=100$ per stand), considering as a gap any area larger than $10 \mathrm{~m}^{2}$ without overhanging tree crowns more than $15 \mathrm{~m}$ tall (Coates and Burton, 1997). Correlations between seedling density and gap percentage and total tree density, and among standing dead and total tree densities, were calculated to test for association between light availability and recruitment or survivorship (Dusan et al., 2007).

A Principal Component Analysis (PCA) was performed for the overall interpretation of structural characteristics and successional ordination of the sampling plots. Based on structural development features proposed by Oliver and Larson (1996), the following variables were included: coefficient of variation (CV) of diameter classes, number of diameter classes (size classes), percentage of gaps, total basal area, number of live trees taller than $4 \mathrm{~m}$, diameter range of live trees (maximum minus minimum stem diameters) and relative density (importance values) of seedlings. PCA results were used to allocate the stands to development stages (Oliver and Larson 1996).

\subsection{Past dynamics reconstruction from radial growth and land-use history}

To reconstruct patterns of stand dynamics in Pinsapo forests following the cessation of major perturbations, we selected the population located at the Yunquera site in the Sierra de las Nieves (stands C1 and C2). Although all our sites had been subjected to intense grazing and logging, the Yunquera-forest was for centuries one of the A. pinsapo populations most intensely grazed and logged by the local inhabitants, until protection measures were implemented in the 1950s (Becerra-Parra, 2006). A total of 83 cross sections from dominant or co-dominant trees, randomly selected and felled in an ongoing thinning experiment, were studied for age determination and radialgrowth analysis.

Cross-sections were sanded until tree rings were clearly visible under a binocular microscope. All samples were visually crossdated. Tree-ring widths were measured to $0.01 \mathrm{~mm}$ using a LINTAB measuring device (Rinntech, Germany) and cross-dating quality was checked using COFECHA (Holmes, 1983). The trend of decreasing ring-width with increasing tree age and size was removed by converting radial increment into tree basal-area increment (BAI). The growth change percentage (GCP) filter of Nowacki and Abrams (1997) was applied to identify abrupt growth reductions or suppressions, i.e. sustained decreases in radial growth. We first calculated the ring-width means of subsequent 10-year periods over all the growth series. Then we defined the percentage of growth reduction as $G C P=[(M 1-M 2) / M 2 \times 100]$, where $M 1$ and $M 2$ are the preceding, and subsequent, 10-year ring-width mean, respectively. Finally, the initial growth rate in relation to the entire chronology was used to distinguish whether trees originated under sunlight conditions or in the understorey. Major and sustained release events were considered as canopy-accession events; each was dated and diameter inside bark (DIB) was calculated; $0.5 \mathrm{~mm} \mathrm{y}^{-1}$ was considered a boundary value in order to distinguish between suppressed and gap-exploiting trees based on radial growth rates (Piovesan et al., 2005; Rozas, 2005).

The impact of forest-use changes on tree regeneration was deduced by comparing historical records of land-use and canopy disturbance events with the tree-establishment data. Anthropogenic activities in the forest were compiled from diverse documentary sources. 

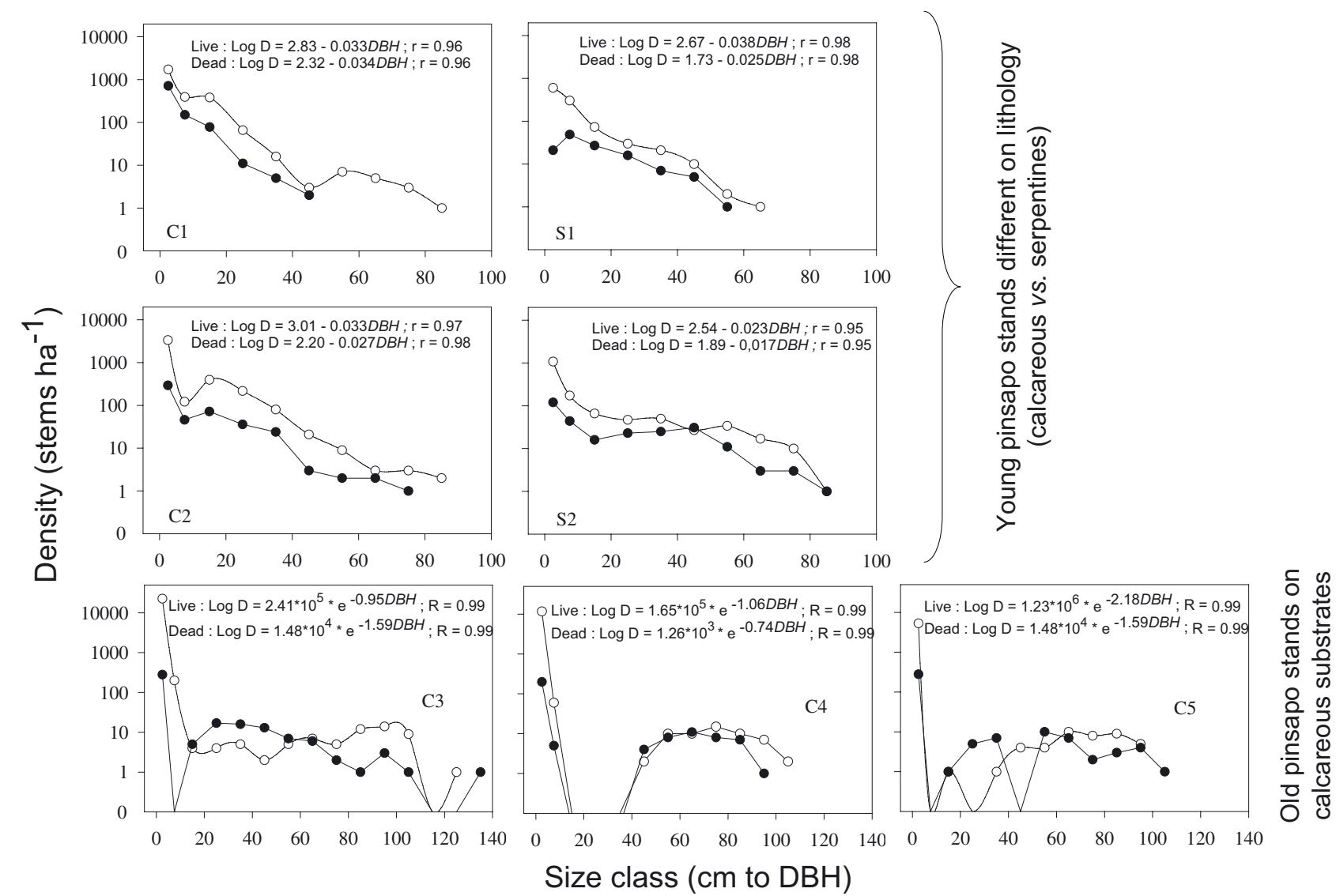

Figure 1. Density by DBH class for live (white circles) and dead (black circles) A. pinsapo stems in the study stands. All correlation coefficients were significant at $\alpha=0.01$ level. Labels of stands: C, calcareous; S, serpentines; 1 , early agradative; 2, stem exclusion; 3 to 5, old-growth.

Key events that presumably implied a significant change in the use of the A. pinsapo forests were documented from publications dealing with forest administration and land-use history; also, a variety of unpublished documents and forest reports were examined.

\section{RESULTS}

\subsection{Stand structure}

Structural properties of the canopy in the studied stands are summarized in Table II. In the forests at Bermeja (S1 and S2) and Yunquera ( $\mathrm{C} 1$ and $\mathrm{C} 2)$, the average basal area was $0.34 \mathrm{~m}^{2} \mathrm{ha}^{-1}$ for young individuals (seedlings and saplings), and $26.0 \mathrm{~m}^{2} \mathrm{ha}^{-1}$ for mature trees. By contrast, in older stands at the Ronda site (C3, C4 and C5), the values were 1.02 and $44.6 \mathrm{~m}^{2} \mathrm{ha}^{-1}$, respectively. Mature dead trees accounted for 7 to $24 \%$ of the total basal area in the younger stands, and for 36 to $43 \%$ in the older ones. Overall, we found a positive relationship between the number of standing dead trees and tree density $\left(y=1.19+0.18 \times x, R^{2}(\operatorname{Adj})=0.92, p<0.05, n=7\right)$.

We found an average of 180 seedlings ha ${ }^{-1}$ with mean age of $2 \mathrm{y}$ in the Bermeja stands on serpentines, about one order of magnitude less than in the Yunquera stands on calcareous substrates (mean age of seedlings $5 \mathrm{y}$ ). Sapling density was also higher in the Yunquera ( 740 saplings ha $\left.{ }^{-1}\right)$ than in the Bermeja forest (380 saplings ha ${ }^{-1}$ ). Calcareous stands showed a significant positive relationship between the number of seedlings and gap percentage $\left(y=-13225.55+553.78 \times x ; R^{2}(\mathrm{Adj})=\right.$ $0.78 ; p=0.03 ; n=5$ ), however far fewer seedlings were recorded at Bermeja compared to regression predictions. No relationship existed between seedling numbers and adult-tree densities. Gap percentage varied between $26 \%$ and $43 \%$ in the stands on calcareous sites, with values generally increasing from younger to older stands.

Expressed on a semi-log scale, tree density per diameter class showed a smooth, continuous, negative decrease from small to large diameters, in the younger stands $(\mathrm{C} 1, \mathrm{C} 2, \mathrm{~S} 1$ and S2; Fig. 1). The slopes of the corresponding linear regressions did not significantly differ among stands (analysis of covariance for live stems: $F=0.05, p>0.05, n=38$; and dead stems: $F=0.21, p>0.05, n=32$ ). On the other hand, log-density per diameter class fitted reverse J-shaped curves (rotated-sigmoid distributions) in the case of the older stands (C3, C4 and C5). Typically, trees corresponding to some of the small to mid-sized-classes (stem diameters in the range $10-40 \mathrm{~cm}$ ) are absent from these stands, indicating the occurrence of minor disturbances in the past. However, the amount of stems less than $10 \mathrm{~cm}$ in diameter was much larger in the 


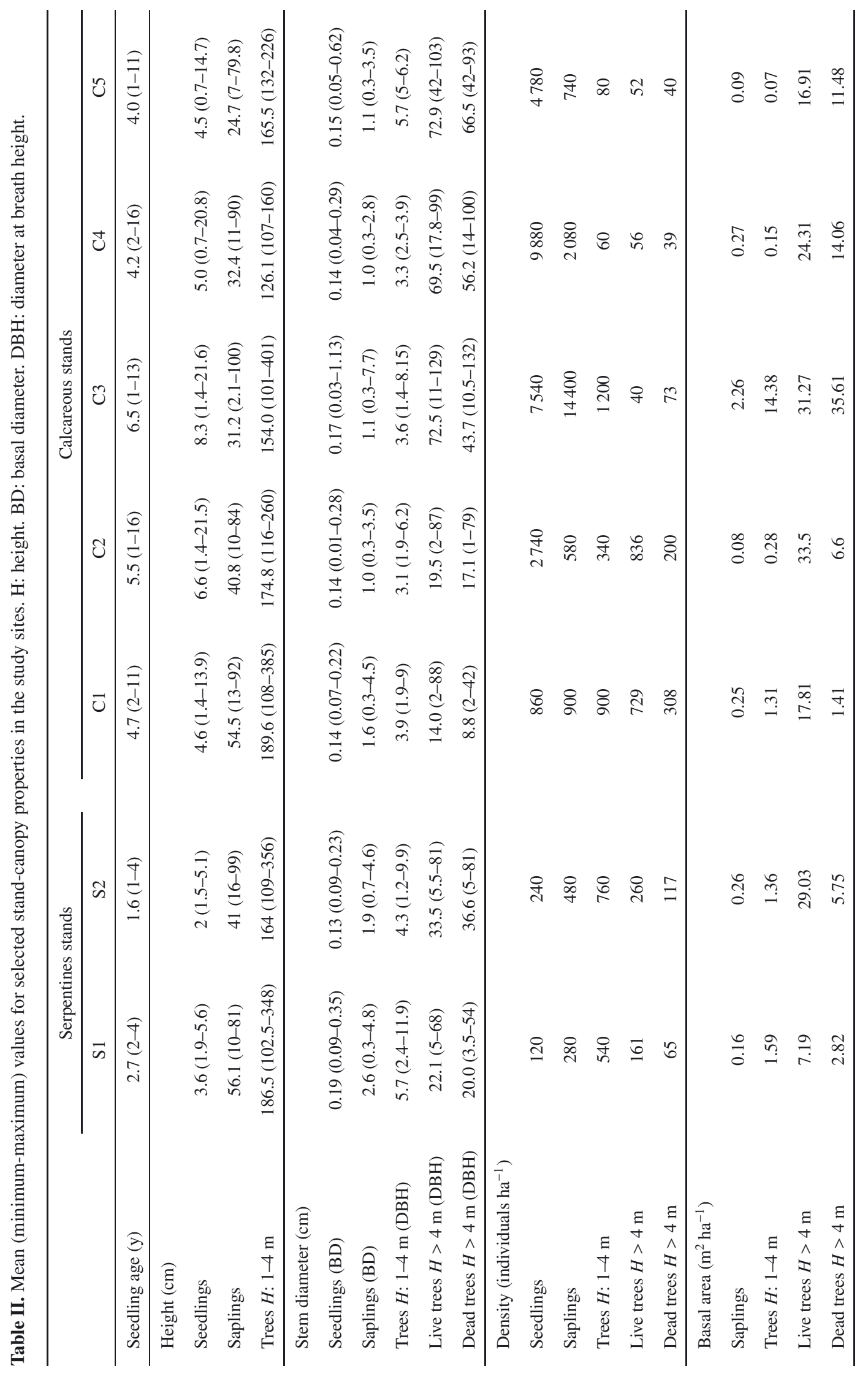


Table III. Loading factors and eigenvalues for the first two axes resulting from a Principal Component Analysis performed on canopy structural variables measured in the selected $A$. pinsapo stands.

\begin{tabular}{lcc}
\hline & PC 1 & PC 2 \\
\hline Loading factor for variable: & & \\
CV of density along diameter classes & 0.81 & -0.42 \\
Number of diameter classes & 0.91 & 0.36 \\
Percentage of gaps & 0.59 & -0.69 \\
Total basal area & 0.77 & 0.48 \\
Density of live trees $>$ 4m high & -0.62 & 0.54 \\
Diameter range of live trees $>$ 4m high & 0.47 & 0.85 \\
Importance values of seedlings & 0.59 & -0.03 \\
\hline Eigenvalues & 3.39 & 2.03 \\
Explained variance (cumulative \%) & 48.4 & 77.4 \\
\hline
\end{tabular}

older than in the young stands. Trees of $70-100 \mathrm{~cm}$ DBH were the most abundant adult trees in the old stands, whereas trees of $10-30 \mathrm{~cm}$ DBH predominated in the younger ones.

Table III shows the eigenvalues and loading factors resulting from the PCA. The first two principal components (PC) accounted for $77.4 \%$ of the total variance of data $(48.4 \%$ the $\mathrm{PC} 1$ and $29.0 \%$ the $\mathrm{PC} 2$ ). The number of diameter classes, the coefficient of variation $(\% \mathrm{CV})$ of densities across diameter classes, and basal area, were the variables showing the highest positive loading factors on the PC1. In addition, the density of live trees taller than $4 \mathrm{~m}$ showed a high but negative loading factor on the PC1. Therefore, PC1 may be regarded as a successional gradient that ordinates stands according to their structural complexity and heterogeneity of size classes. Regarding the PC2, high and positive loading factors were shown by variables related to the abundance of big trees and dense canopies, such as the diameter range and density of live trees taller than $4 \mathrm{~m}$. A high and negative loading factor was shown by the percentage of gaps. Therefore, $\mathrm{PC} 2$ can be regarded as a gradient of canopy closure. The observation of a loading factor on PC2 close to 0 for the importance values of seedlings suggest that $A$. pinsapo seedlings are shade-tolerant and, thus, that a high density of mature trees and canopy closure do not necessarily imply a lower relative frecuency of seedlings. The ordination of sampling plots by the first two axes of the PCA is shown in Figure 2.

The PCA results allow the allocation of the stands to development phases. Stands projected onto the negative part of the PC1 can be assigned to the stem exclusion stage, whereas stands projected onto its positive part show old-growth stage features. Likewise, the PC2 ordinates the stands in terms of increasing degree of canopy closure (from left to right). Figure 2 illustrates that dense $A$. pinsapo stands $(\mathrm{C} 1, \mathrm{C} 2$ and $\mathrm{C} 3$ ) may correspond to a wide range of structural and successional stages; and that older stands (C3, C4 and C5) may exhibit a wide range of canopy closure.

\subsection{Age structure, growth history and dendroecology}

Age distributions of the trees studied at the Yunquera site comprised two main cohorts separated by periods that

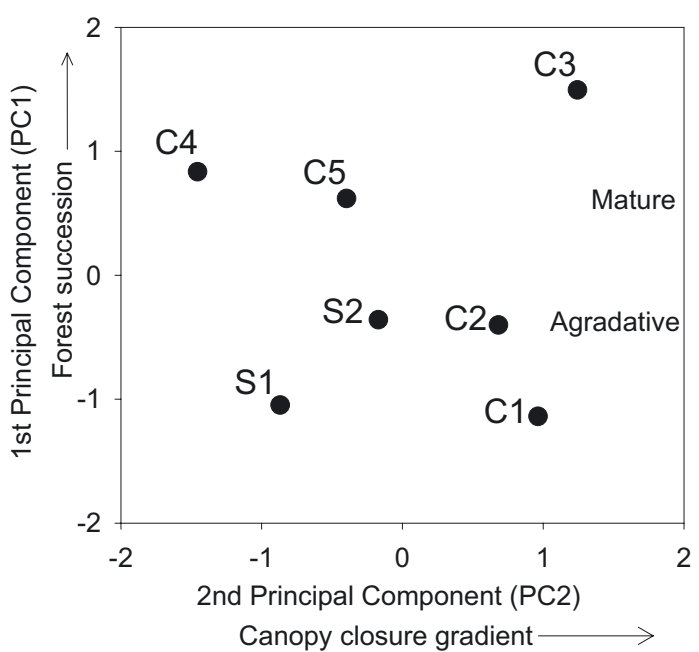

Figure 2. Plot ordination based on the two first axes resulting from a Principal Component Analysis on canopy structural variables. The projections of sampling stands (C, calcareous; $\mathrm{S}$, serpentines) on the PC1 match up with the initial arrangement of their stand successional stage (1, early agradative; 2 , stem exclusion; 3 to 5 , old-growth) based on historical management data and observational field surveys. PC2 is related to the degree of canopy closure. Eigenvalues and loading factors are listed in Table III.

ranged from 20 to $40 \mathrm{y}$. Mean diameter increment was $1.51 \pm$ $0.06 \mathrm{~mm} \mathrm{y}^{-1}$ (mean \pm standard error, $n=83$ ), ranging from 0.74 to $3.88 \mathrm{~mm} \mathrm{y}^{-1}$. A positive and linear relationship was found between mean growth and DBH (Mean growth $=0.33+$ $\left.0.06 \times \mathrm{DBH} ; R^{2}(\mathrm{Adj})=0.70 ; p<0.01 ; n=83\right)$, and between age at breast height and DBH $(\mathrm{Age}(\mathrm{DBH})=45.55+$ $\left.0.89 \times \mathrm{DBH} ; R^{2}(\mathrm{Adj})=0.19 ; p<0.01 ; n=83\right)$. Because of the different growth history of the studied trees, only a small percentage $(19 \%)$ of the variance in age was explained by DBH. Age at breast height varies between 49 and $102 \mathrm{y}$, with a mean age of $61.47 \pm 1.35 \mathrm{y}$. Establishment of new cohorts, in a stand previously composed of scattered trees, suddenly began around $60 \mathrm{y}$ ago, peaked in the 55-65 y age-class (64\% of studied trees were between 55 and $65 \mathrm{y}$ old), and ceased 25-30 y ago (Fig. 3).

Based on the above Age/DBH relationship, the biggest tree (located in stand C3, $132 \mathrm{~cm} \mathrm{DBH}$ ) had an estimated age of 163 y old. Mature trees ( $>4 \mathrm{~m}$ tall) in C3 averaged 94 y old. Estimated mean (maximum) ages of mature trees for the rest of the study stands were: 33 (72) and 22 (58) in the young stands S1 and C1; 48 (104) and 30 (101) in the intermediate stands S2 and C2; and 91 (125) and 95 (117) in the old stands $\mathrm{C} 4$ and $\mathrm{C} 5$.

Mean basal area increment (BAI) was higher in older trees (Fig. 4). Old trees retained higher growth despite age: BAI ranged from $20 \mathrm{~cm}^{2} \mathrm{y}^{-1}$ in $>100 \mathrm{yr}$-old trees, to $\sim 5 \mathrm{~cm}^{2} \mathrm{y}^{-1}$ in trees younger than this age. Moreover, BAI was linked to present day DBH: there was a tendency for higher growth rates to be expressed in larger trees. For the last ten years, BAI was lower than $10 \mathrm{~cm}^{2} \mathrm{y}^{-1}$ in $91 \%$ of studied trees and only 1 tree showed a BAI higher than $20 \mathrm{~cm}^{2} \mathrm{y}^{-1}$. The differences 


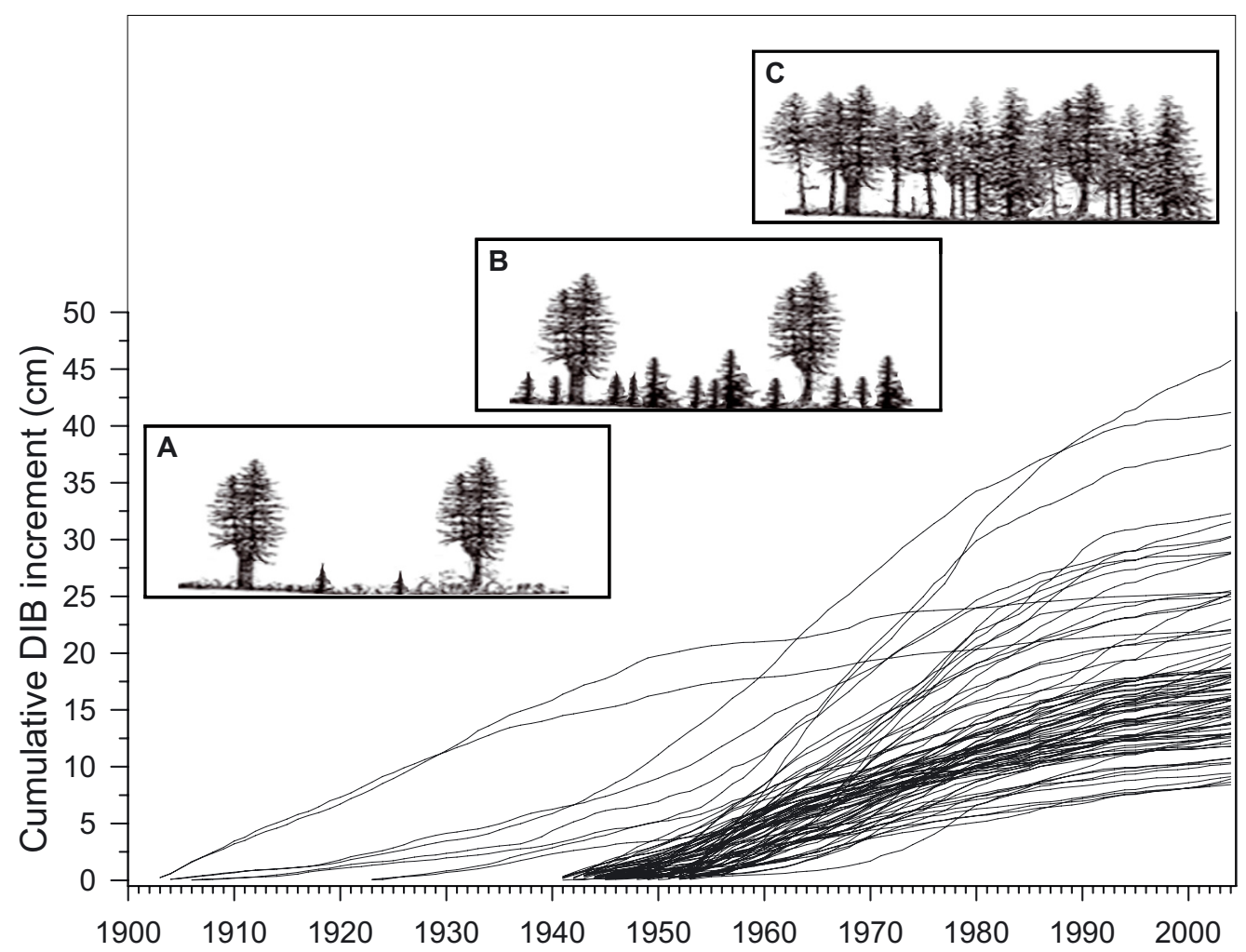

Figure 3. Cumulative diameter inside bark (DIB) increment for dominant and co-dominants trees $(n=83)$ from the Yunquera site. A. pinsapo stand development is illustrated in three stages: uneven aged scattered remaining trees until 1950s (A), establishment of new cohorts from the second half of the 20th century (B), and complete canopy closure and substantial class size differentiation (C). Each black line corresponds to one sampled tree.

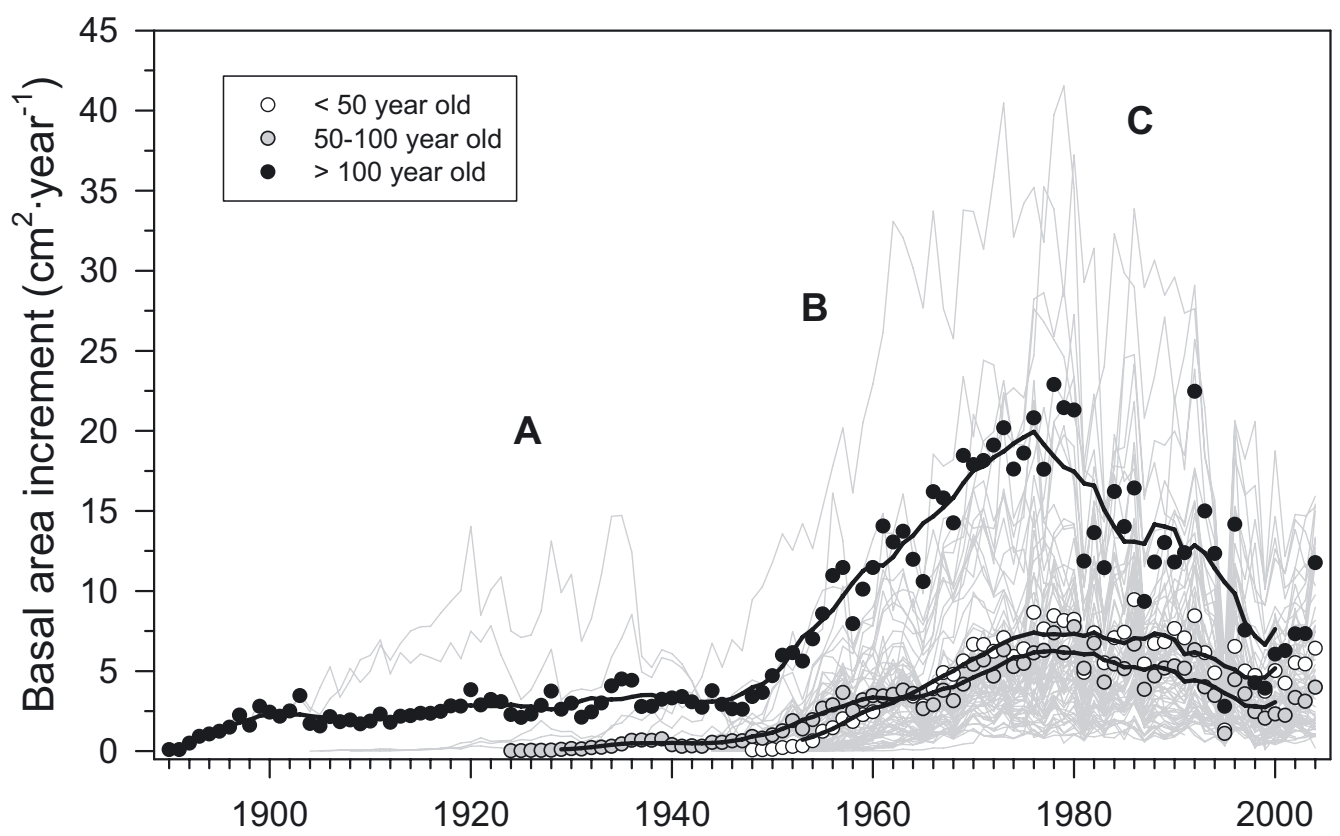

Figure 4. Mean basal area increment (BAI) over time for dominant and co-dominant trees less than 50 years old (white circles), between 50 and 100 y old (gray circles), and more than 100 years old (black circles). Secondary growth showed a low BAI until 1950s (A), establishment of new cohorts and positive trend until the end of the 1970s (B), and growth decrease in the three last decades of the 20th century (C). Each gray line corresponds to one sampled tree. 


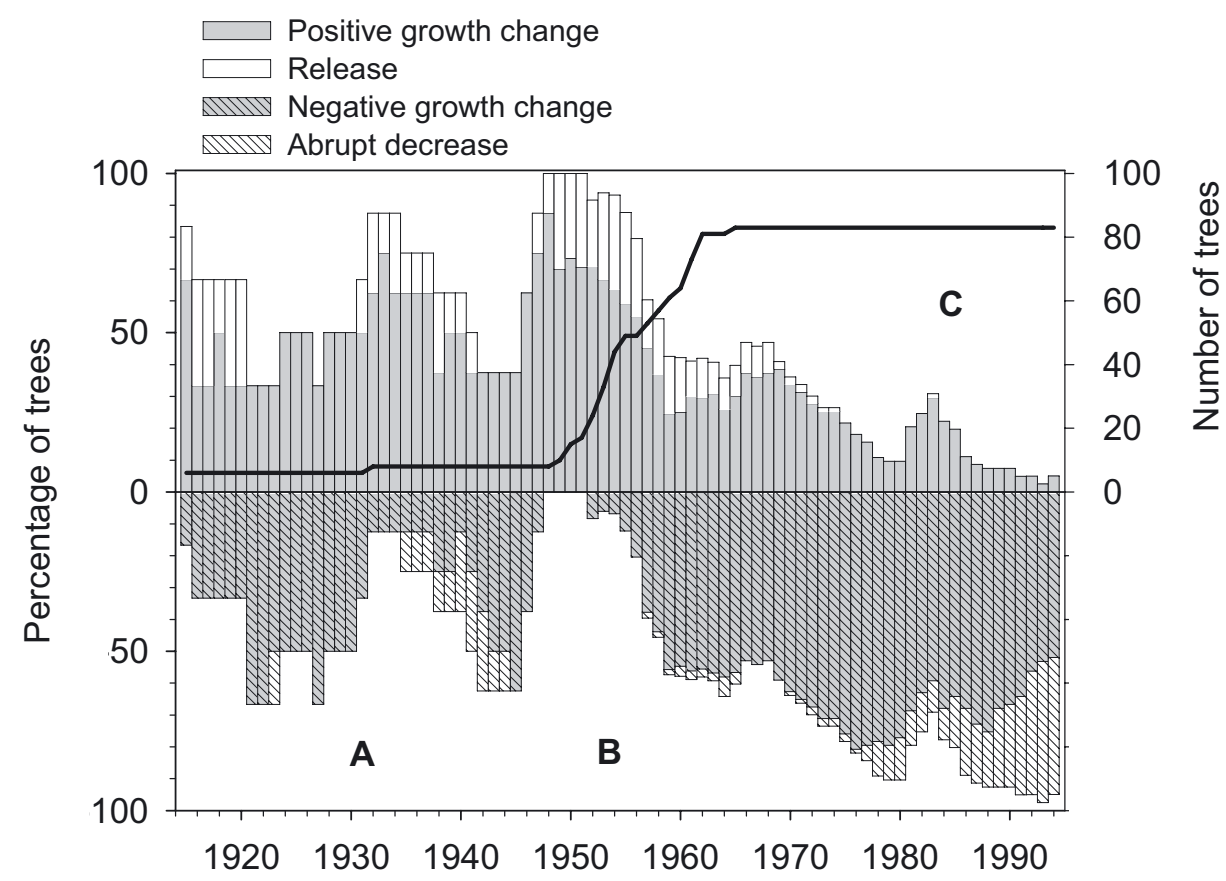

Figure 5. Annual distribution of releases (top white bars) and abrupt decreases (bottom light bars) based on growth change percentage (GCP) values. Frequency of trees with positive and negative GCP is also shown. Solid line represents the number of trees that reached the height of diameter at breast height (DBH) at this year. Growth trend showed oscillating periods of positive and negative GCP until 1950s (A), release and stem reinitiation in the 1950s (B), and widespread decrease after full site occupancy (C).

in growth rates between trees have narrowed in the last years, when all age classes have shown a pattern of decreasing BAI with time. This pattern started around 1980 for the oldest class and during the 90 s for the younger ones, which had shown consistently low values of growth in the last $30 \mathrm{y}$.

According to the study of initial growth rates and timing of release, trees with high initial growth rates followed by a decline or no trend are considered to have originated in large gaps, with unobstructed access to the canopy. Trees that originated in the understorey are expected to have low initial growth rates but an increasing trend afterwards. An intermediate category is made up of small-gap trees, which originated in canopy openings that later closed by lateral expansion of gap bordering individuals. We estimated that $54 \%$ of trees originated in small gaps, $31 \%$ originated in large gaps, and the remaining $15 \%$ originated in the understorey. The analysis revealed a wide range of initial growth rates prior to reaching the canopy, probably due to the continuum of light levels between gap and non-gap situations. Canopy accession from the understorey was attained with a mean DIB of $2.80 \mathrm{~cm}$ (range from 7.84 to $0.55 \mathrm{~cm}$ ), after a mean understorey residence time of $19 \mathrm{y}$ (range from 5 to $49 \mathrm{y}$ ) showing a mean annual radial growth of $0.33 \mathrm{~mm} \mathrm{y}^{-1}$ (range from 0.16 to $0.47 \mathrm{~mm} \mathrm{y}^{-1}$ ). By contrast, trees in small gaps showed a mean annual radial growth of $0.99 \mathrm{~mm} \mathrm{y}^{-1}$ (range from 0.51 to $1.48 \mathrm{~mm} \mathrm{y}^{-1}$ ) before canopy accession.

All trees younger than 100 y old underwent a sustained release in the 1950s. Older trees showed two events of sustained release, in 1915 and in 1933 . Finally, more than $50 \%$ of the sampled trees showed a permanent growth reduction in the last $20 \mathrm{y}$, whereas only one previous event of such kind, dated around 1941, could be found and it affected less than $40 \%$ of the trees (Fig. 5).

\section{DISCUSSION}

The structural analysis enabled us to differentiate two main groups of stands among the $7 \mathrm{~A}$. pinsapo studied stands (Fig. 2). Firstly, in 4 stands, populations in early-agradative and stem-exclusion stages established once protection policies were implemented, and, secondly, in 3 stands, remnant $A$. pinsapo populations with canopy-structural attributes characteristic of old-growth forests (Oliver and Larson, 1996). Pinsapo forests have a multilayered canopy and a strong dependence for tree recruitment on gap formation and light availability (Arista, 1995), both common characteristics of temperate coniferous forests. The gap fraction found (34\% on average) was within the range reported for boreal and subalpine fir forests $(6-36 \%)$, and higher than that in temperate hardwoods (2-20\%) or coniferous forests (11-18\%) (McCarthy, 2001). Seedling density correlated positively with the percentage of gaps. Nevertheless, the number of $A$. pinsapo seedlings in stands on serpentines soils was much lower than expected according to tree density and gap percentage in these stands, and their young mean age indicates high mortality. The phytotoxic nature of serpentines soils (Proctor, 1999), a lack of 
adequate regeneration niches and reduced seed yields (personal observation) may explain this difference.

We found that establishment of $A$. pinsapo saplings was mainly associated with small canopy gaps. A similar result was obtained by Arista, (1995) in the Sierra de Grazalema Pinsapo forest, as well as a similar maximum understorey residence time of about $40 \mathrm{y}$ ( $49 \mathrm{y}$ in our study). However, other Abies species have been reported to regenerate in gaps of all sizes (Foster and Reiners, 1986; Dobrowolska and Veblen, 2008) and to have longer understorey residence times. For instance, European silver fir (Abies alba Mill.) sapling ages might vary between 11 and $101 \mathrm{y}$ (mean value $46 \pm 22 \mathrm{y}$; see Szymura, (2005)). Furthermore, the age of canopy accession ranged between 15 and 93 y (mean $47 \pm 19$ y) (Nagel et al., 2007; Szymura, 2005). It is likely that summer drought limits the capacity of $A$. pinsapo to survive deep shade in a suppressed status under the canopy for periods as long as those described for Abies species in temperate or boreal regions (Valladares and Pearcy, 2002).

Despite a physiognomy that resembles that of temperate fir forests, several features related to climate conditions and long and intense human impact make circum-Mediterranean fir forests different from those of the rest of Europe and North America (Grove and Rackham, 2001). Mountain areas around the Mediterranean basin are refuges for relict conifer tree species (e.g., circum-Mediterranean fir species), as well as for genetically valuable isolated populations of tree species for which the core-distribution range is located at higher latitudes, in temperate regions (e.g., Pinus sylvestris, Taxus baccata). Thus, to some extent, these mountain areas represent temperate-like biome "islands" within the Mediterranean-type climate region, and are expected to be particularly vulnerable to the effects of ongoing climate change (Boisvenue and Running, 2006). Following intense historic land-use, many of these areas underwent the abandonment of traditional uses. Thereafter, no-management or minimum management options have been commonly applied in the territories occupied by these forests (IPCC, 2007). Consequently, the absence of a natural low level disturbance regime has led to increasing stocking density in these forests during recent decades, resulting in the enhancement of density-dependent factors and a low canopy-structural diversity at the stand level.

In these A. pinsapo forests, severe restriction of traditional uses by local communities (tree pollarding, charcoal production, and uncontrolled grazing) took place at the onset of the 1950s (Alvarez, 1994). The observed discontinuity in tree establishment over time (Fig. 3) and the current stand structure (Fig. 1) in the agradative Yunquera forest can be matched to known changes in forest use. Prior to the 1950s (see stage A in Figs. 3, 4 and 5), this site had been subjected to intensive grazing and logging by the local population for centuries (Ceballos and Bolaños, 1928). In the same sense, old-growth stands in the Ronda forest currently show abundant regeneration (inverse J-shaped density histograms) but several tree-size classes are absent from the canopy (Fig. 1), which is symptomatic of a history of intermittent, not continuous, heavy grazing by domestic animals, that precluded tree establishment during some periods (Laguna, 1868). However, Arista, 1995 found a contin- uous diameter distribution in the Sierra de Grazalema Pinsapo forest, which suggests a multi-age structure from a continuous regeneration pattern and gap-type dynamics (Veblen, 1992).

In the Yunquera forest, we dated a noticeable release event in the 1950s, which presumably took place from existing banks of $A$. pinsapo saplings suppressed due to grazing, as well as an increasing number of trees reaching the canopy. During this period, all the trees studied showed a positive GCP, and the GCP and BAI of mature trees were above average, indicating that the forest canopy was not as dense as in more recent periods (see stage B in Figs. 3, 4 and 5). Throughout the 1970s, an increasing number of trees began to show negative GCP (some of them abruptly, with GCP > 100\%), the BAI of mature trees entered an asymptotic trend, and the canopy closure was likely completed (see stage C in Figs. 3, 4 and 5). In the last twenty years, competition and possibly climatic change might explain the general reduction in tree growth in the Yunquera forest, as also reported for the Ronda forest (Génova, 2007). Both global warming and stand stagnation may have caused recent growth reduction and currently low growth rates. Climate change models for south Mediterranean Spain predict a decrease in annual mean precipitation between 6 and 14\% (Sumner et al., 2003). Additionally, IPCC (2007) predicts an increase in temperature for these areas in the next century. The frequency of extreme droughts may increase in the future, which could lead to a reduction of Pinsapo forest productivity and decline in populations subjected to high intra-specific competition.

Acknowledgements: The authors are grateful to Dr. J.J. Camarero for their dendroecological lessons. We also express our gratitude to Mr. Jose Quintanilla and Mr. Miguel A. Catalina, and to the forest agents Mr. Jose L. Merida, Mr. Andres Madrid, Mr Fernando Ríos and Mr. Isidoro Vera. This work was financed through the Spanish Ministry of Science and Technology projects PB98-0309 and BOS2000-0897. We wish to thank to Consejería de Medio Ambiente (Junta de Andalucía) for providing sampling permissions, accommodation, access, and installation of fences in the study sites as well as available information on A. pinsapo forests. We thank G. Aussenac and two anonymous reviewers for improving a previous version of this manuscript.

\section{REFERENCES}

Abrams M.D. and Orwig D.A., 1996. A 300-year history of disturbance and canopy recruitment for co-occurring white pine and hemlock on the Allegheny Plateau, USA, J. Ecol. 84: 353-363.

Alvarez C.M., 1994. Los pinsapares malagueños en el recuerdo. In: Gestión y conservación de los pinsapares andaluces, Asociación forestal andaluza, pp. 77-90.

Antos J.A. and Parish R., 2002. Structure and dynamics of a nearly steady-state subalpine forest in south-central British Columbia, Canada, Oecologia 130: 126-135.

Arista M., 1995. The structure and dynamics of an Abies pinsapo forest in Southern Spain. For. Ecol. Manage. 74: 81-89.

Aussenac G., 2002. Ecology and ecophysiology of circum-Mediterranean firs in the context of climate change. Ann. For. Sci. 59: 823-832.

Barbero M. and Quézel P., 1975. Les forets de Sapin sur le pourtour méditerranéen. Anal. Inst. Bot. Cabanilles 32: 1245-1289. 
Becerra-Parra M., 2006. Ordenación y aprovechamiento de los pinsapares rondeños durante el siglo XIX. La memoria de Antonio Láynez. Editorial La Serranía, SLL, Ronda, Spain.

Benayas J.M.R., 1998. Growth and survival in Quercus ilex L. seedlings after irrigation and artificial shading on Mediterranean set-aside agricultural land. Ann. Sci. For. 55: 801-807.

Boisvenue C. and Running S.W., 2006. Impacts of climate change on natural forest productivity-evidence since the middle of the 20th century. Global Change Biol. 12: 1-12.

Brady K.U., Kruckeberg A.R., and Bradshaw Jr.H.R., 2005. Evolutionary ecology of plant adaptation to serpentine soils. Ann. Rev. Ecol. Evol. Syst. 36: 43-66.

Ceballos L. and Bolaños M., 1928. Notas sobre el aspecto botánicoforestal de la Serranía de Ronda y Grazalema, IFIE, Madrid.

Coates K.D. and Burton P.J., 1997. A gap-based approach for development of silvicultural systems to address ecosystem management objectives. For. Ecol. Manage. 99: 337-354.

Dobrowolska A. and Veblen T.T., 2008. Treefall-gap structure and regeneration in mixed Abies alba stands in central Poland. For. Ecol. Manage. 255: 3469-3476.

Donnegan J.A. and Rebertus A.J., 1999. Rates and mechanisms of subalpine forest succession along an environmental gradient. Ecology 80: $1370-1384$.

Dusan R., Stjepan M., Igor A., and Jurij D., 2007. Gap regeneration patterns in relationship to light heterogeneity in two old-growth beechfir forest reserves in South East Europe. Forestry 80: 431-443.

Foster J.R. and Reiners W.A., 1986. Size distribution and expansion of canopy gaps in a northern Appalachian spruce-fir forest. Plant Ecol. 68: $109-114$.

Génova M., 2007. El crecimiento de Abies pinsapo y el clima de Grazalema: aportaciones dendroecológicas. Invest. Agr.: Sist. Recur. For. 16: 145-157.

Grove A.T. and Rackham O., 2001. The nature of Mediterranean Europe: an ecological history, Yale University Press, New Haven.

Holmes R.L., 1983. Computer-assisted quality control in tree-ring dating and measurement. Tree-Ring Bull. 43: 68-78.

IPCC, 2007. Afforestation, reforestation, and deforestation (ARD) activities, IPCC special report on land Use, land-use change and forestry.

Kneeshaw D.D. and Bergeron Y., 1998. Canopy gap characteristics and tree replacement in the southeastern boreal forest. Ecology 79: 783-794.

Laguna M., 1868. El pinsapar de Ronda, Revista Forestal.
Liétor J., Linares J.C., Martín-García J.M., García-Ruíz R., and Carreira J.F., 2003. Relaciones suelo-planta en bosques de Abies pinsapo Boiss. Disponibilidad de nutrientes y estatus nutricional. Acta Botánica Malacitana 28: 89-104.

Lookingbill R.T. and Zavala M.A., 2000. Spatial pattern of Quercus ilex and Quercus pubescens recruitment in Pinus halepensis dominated woodlands. J. Veg. Sci. 11: 607-612.

McCarthy J., 2001. Gap dynamics of forest trees: A review with particular attention to boreal forests. Environ. Rev. 9: 1-59.

Nagel T.A., Levanic T., and Diaci J., 2007. A dendroecological reconstruction of disturbance in an old-growth Fagus-Abies forest in Slovenia. Ann. For. Sci. 64: 891-897.

Nolet P., Delagrange S., Bouffard D., Doyon F., and Forget E., 2008. The successional status of sugar maple (Acer saccharum), revisited. Ann. For. Sci. 65: 208.

Nowacki G.J. and Abrams M.D., 1997. Radial-growth averaging criteria for reconstructing disturbance histories from presettlement-origin oaks. Ecol. Monogr. 67: 225-249.

Oliver C.D. and Larson B.C., 1996. Overview of stand development patterns. In: Forest stand dynamics, Wiley, New York, pp. 145-167.

Pausas J.G., 1999. Mediterranean vegetation dynamics: modelling problems and functional types. Plant Ecol. 140: 27-39.

Piovesan G., Di Filippo A., Alessandrini A., Biondi F., and Schirone B., 2005. Structure, dynamics and dendroecology of an old-growth Fagus forest in the Apennines. J. Veg. Sci. 16: 13-28.

Proctor J., 1999. Toxins, nutrient shortages and droughts: the serpentine challenge. Trends Ecol. Evol. 14: 334-335.

Rozas V., 2005. Dendrochronology of pedunculate oak (Quercus robur L.) in an old-growth pollarded woodland in northern Spain: establishment patterns and the management history. Ann. For. Sci. 62: 13-22.

Sumner G.N., Romero R., Homar V., Ramis C., Alonso S., and Zorita E., 2003 An estimate of the effects of climate change on the rainfall of Mediterranean Spain by the late twenty first century. Clim. Dyn. 20: 789-805.

Szymura T.H., 2005. Silver fir sapling bank in seminatural stand: Individuals architecture and vitality. For. Ecol. Manage. 212: 101-108.

Valladares F. and Pearcy R.W., 2002. Drought can be more critical in the shade than in the sun: a field study of carbon gain and photoinhibition in a Californian shrub during a dry El Niño year. Plant Cell Environ. 25: 749-759.

Veblen T.T., 1992. Regeneration dynamics. In: Glenn-Lewin D.C., Peet R.K., Veblen T.T. (Eds.), Plant succession: Theory and prediction, Chapman and Hall, London, pp. 152-187.

Vilà M. and Sardans J., 1999. Plant competition in Mediterranean-type vegetation. J. Veg. Sci. 10: 281-294. 